\title{
Estimation of the Heat Flow Variation in the Chad Basin Nigeria
}

\author{
NWANKWO, CYRIL N.; EKINE, ANTHONY S.; NWOSU, LEONARD I.
}

\author{
Department of Physics, University of Port Harcourt, Nigeria
}

\begin{abstract}
Wireline logs from 14 oil wells from the Nigerian sector of the Chad Basin were analyzed and interpreted to estimate the heat flow trend in the basin. Geothermal gradients were computed from corrected bottom hole temperatures while the bulk effective thermal conductivity for the different stratigraphic units encountered in the wells were computed from the sonic logs data. The heat flow values were then calculated. A corrected average geothermal gradient of $3.4 \mathrm{oC} / 100 \mathrm{~m}$ and a regional range of 3.0 to $4.4 \mathrm{oC} / 100 \mathrm{~m}$ were obtained. A porosity range of 2 to $79 \%$ and average of $35 \%$ were computed for Chad Basin Nigeria. Also the thermal conductivities vary from 1.70 and $3.11 \mathrm{Wm}^{-1} \mathrm{C}^{-1}$, with an average value of $2.35 \mathrm{Wm}^{-1} \mathrm{C}^{-1}$ computed for the various wells in the basin. A large variation in heat flow was recorded within the basin. Mean heat flow values computed for the basin vary from 63.6 to $105.6 \mathrm{mWm}^{-2}$, with a simple average of $80.6 \mathrm{mWm}^{-2}$. Although there is no distinct trend on heat flow within the basin, the computed heat flow values are relatively lower at the southwestern and northeastern axis of the basin. And the values obtained in this study compared favorably with those of other world sedimentary basins (including Niger Delta) that are of similar history with the Chad Basin, suggesting that the Nigerian Chad Basin is a possible petroliferous basin. @ JASEM
\end{abstract}

The present day national petroleum reserves asset of about 32 billion barrels of oil and 170 trillion standard $\mathrm{ft}^{3}$ of gas (Obaje et al., 2004), are derived solely from the onshore and offshore of Niger Delta Basin. Thus, in the recent past most researchers and scholars on petroleum potentials in Nigeria have concentrated mostly in the Southern basins (Niger Delta and Anambra Basins) and most recently in Benue Trough, while little geophysical work has been carried out in the Nigerian Chad Basin. This is despite the Federal Government's huge investment in the exploration of oil and gas in this region.

At steady state, the heat flow within the sediment is in equilibrium with the surface temperature and the heat flow at the base of the basin. However, rapid deposition of sediments or the removal of material by erosion involves transient effects that will result in temporary thermal disequilibrium.

Heat flow measurements in regions of the Earth provide important and significant tool for interpreting the tectonic evolution and the ongoing thermal processes within the regions of the Earth. Heat flow data contribute towards better understanding of tectonic and geologic processes including rifting, plateau uplift and mountain building, as well as providing the necessary conditions for the analysis of hydrocarbon maturation in sediments (Nwankwo, 2007).

Basic data used for this work are geophysical logs (Gamma ray, Resistivity and Sonic logs) from 14 exploratory wells in the Chad Basin Nigeria. Though the available data vary in completeness and quality, this study has helped to increase our knowledge and understanding of the geology, petroleum prospect and potentials of the Chad Basin by establishing the thermal conductivity and heat flow values of the basin.

\section{REGIONAL GEOLOGICAL SETTING}

The Chad Basin lies within a vast area of Central and West Africa at an elevation of between $200 \mathrm{~m}$ and $500 \mathrm{~m}$ above sea level. The basin is centered around lake Chad (Fig. 1) and occupies an area of approximately 2,500, $000 \mathrm{~km}^{2}$ extending over parts of the Republic of Niger, Chad, Sudan and the northern portions of Cameroon and Nigeria. The origin of the Chad Basin has been generally attributed to the rift system that developed in the early Cretaceous when the African and South American lithospheric plates separated and the Atlantic opened. Pre-Santonian Cretaceous sediments were deposited within the rift system.

The Nigerian sector of the Chad Basin constitutes only about $6.5 \%$ of the entire basin and extends $152,000 \mathrm{~km}^{2}$ of territory in Borno, Bauchi, Plateau and Kano States. The altitude of the basin ranges from $300 \mathrm{~m}$ within the lake to about $530 \mathrm{~m}$ at the western margin, along a distance of about $240 \mathrm{~km}$. The Basin has developed at the intersection of many rifts, mainly in an extension of the Benue Trough. Major grabens then developed and sedimentation started. 


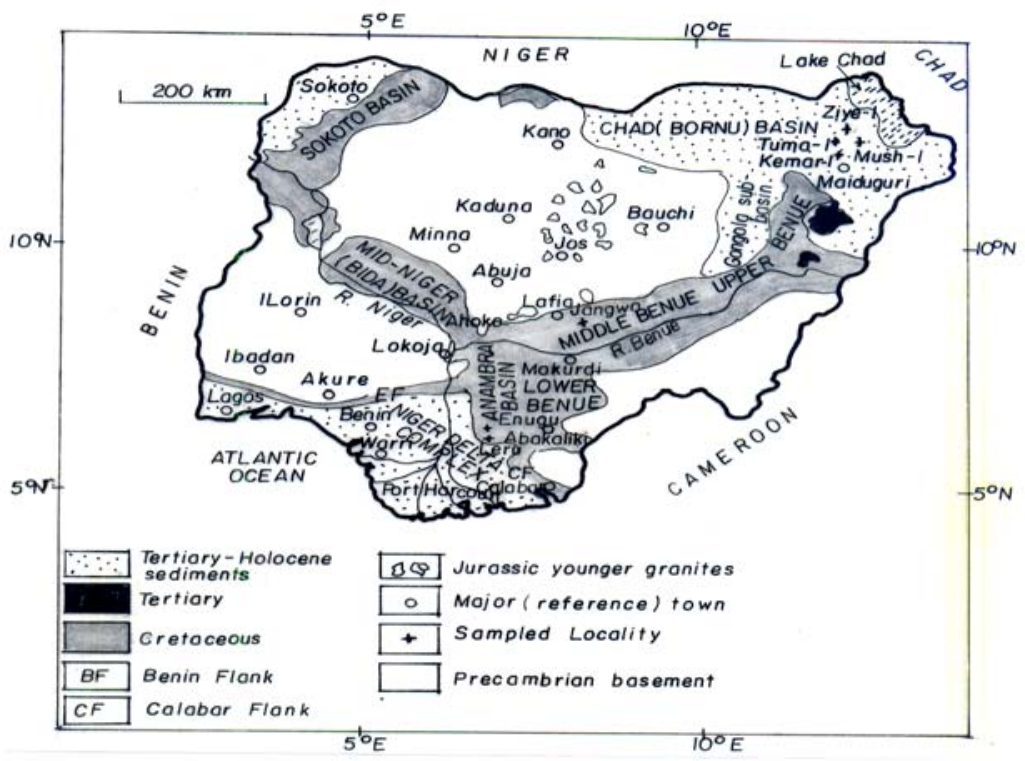

Fig. 1: Geologic map of Nigeria showing the Chad Basin (adapted from Obaje et al., 2004)

Sedimentary sequence span from the Paleozoic to Recent accompanied by a number of stratigraphic gaps. Sediments are mainly continental, sparsely fossiliferous, poorly sorted, and medium to coarsegrained, feldspathic sandstones called the Bima Sandstone. A transitional calcerous deposit - Gongila Formation that accompanied the onset of marine incursions into the basin, overlies the Bima Sandstones. These are overlain by graptolitic shale.

\section{DATA ACQUISITION AND ANALYSIS}

In this study, the gamma ray logs were utilized to delineate the sediments bed boundaries for the various formations (sandstone, shale and siltstone) encountered. Three major sediment packages - the Bima Formations, Gongila-Fika Shale and the Chad Formations has been identified. The gamma ray response indicates the dominant Chad Formation clearly, but shows very little variations in Fika Frmation. Also the resistivities in Fika Formation are generally low with high peaks in areas suspected to be associated with intrusives. The base of the Gongila Formation is mostly recognized by an increase in gamma ray response as it passes into the Bima. Fig. 2 depicts the generalized well lithology estimated from this study.

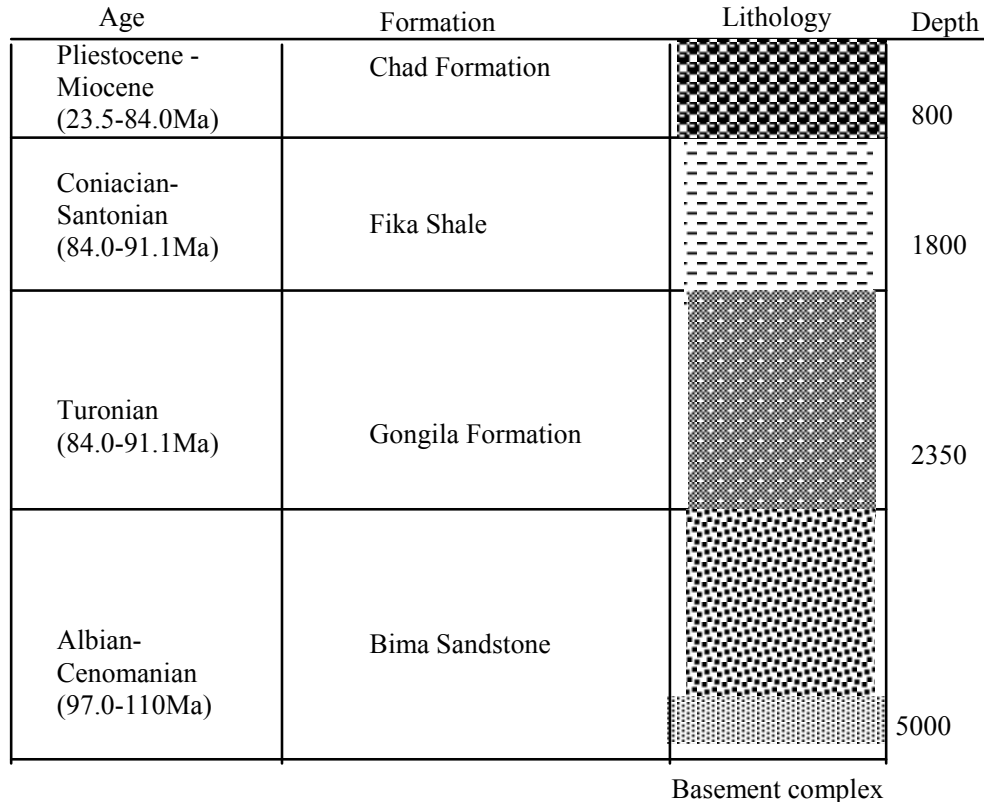

Fig. 2: Generalised well lithology for Chad Basin Nigeria

* Corresponding author: Nwankwo, Cyril N. 


\section{Basin Porosity variation}

A relationship defining a uniform inter granular porosity in terms of total formation velocity, rock matrix velocity, and fluid velocity is given as:

$1 / \mathrm{v}=\varphi / \mathrm{v}_{\mathrm{f}}+(1-\varphi) / \mathrm{v}_{\mathrm{m}}$

where $\varphi=$ fractional porosity of the rock

$\mathrm{v}=$ velocity of formation in $\mathrm{m} / \mathrm{sec}$

$\mathrm{v}_{\mathrm{f}}=$ velocity in interstitial fluids in $\mathrm{m} / \mathrm{sec}$

$\mathrm{v}_{\mathrm{m}}=$ velocity of the rock matrix in $\mathrm{m} / \mathrm{sec}$.

Equation (3) can be re-written to express porosity in terms of the reciprocal of velocity $\Delta t$, or specific acoustic travel time:

$$
\varphi=\frac{\Delta t-\Delta t_{m}}{\Delta t_{f}-\Delta t_{m}}
$$

\section{Porosity (\%)}

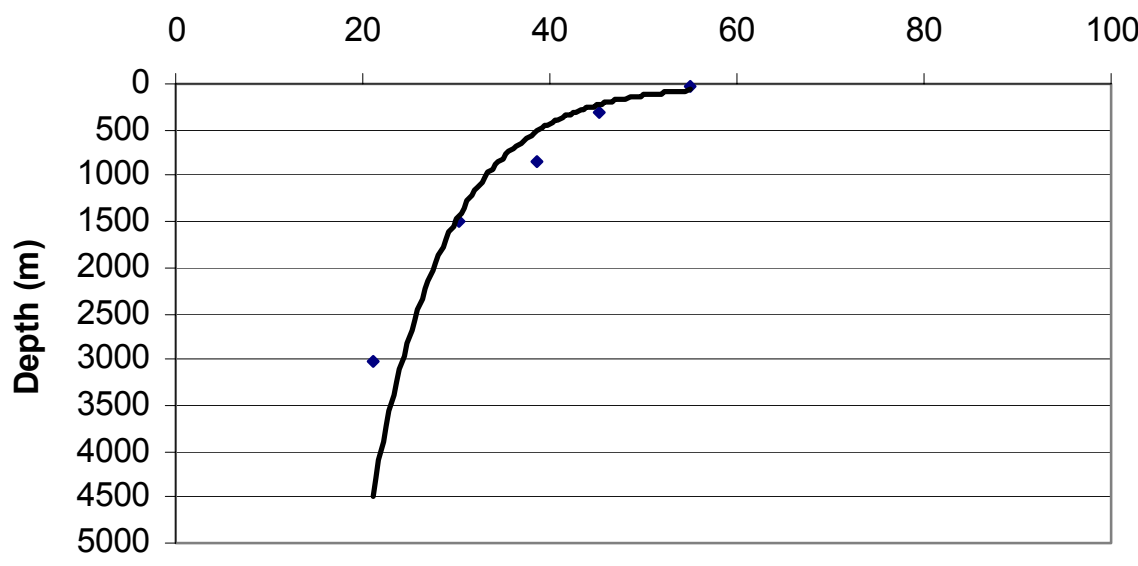

where $\Delta \mathrm{t}=$ acoustic travel time from the bottom hole compensated acoustic log in $\mu \mathrm{sec} / \mathrm{m}$

$\Delta \mathrm{t}_{\mathrm{m}}=$ acoustic travel time of the rock matrix in $\mu \mathrm{sec} / \mathrm{m}$

$\Delta \mathrm{t}_{\mathrm{f}}=$ acoustic travel time of interstitial fluids in $\mu \mathrm{sec} / \mathrm{m}$

Equation (4) has been utilized to estimate the sediment porosities at various stratigraphic units. Porosities in Chad Formation vary between 3.12 and $79.0 \%$ with an average value of $44.7 \%$. in the Fika Shales, the porodity varies from $9.38 \%$ to $73.91 \%$, and a simple average of $36.18 \%$. The porosity variation in Gongila Formation is between 9.37 and $72.34 \%$, with an average value of $35.90 \%$. That of the Bima Sandstone varies from $1.96 \%$ to $62.06 \%$. An average value of $11.29 \%$ was obtained for this interval. Fig. 3 shows the plot of the exponential porosity-depth relation for Kanadi-1 well. Also, porosity profiles for sandstone, shale and siltstone lithologies deposited in the basin are shown in Fig. 4 -6 .

Fig 3: Depth - Porosity Variation for Kanadi-1 well 


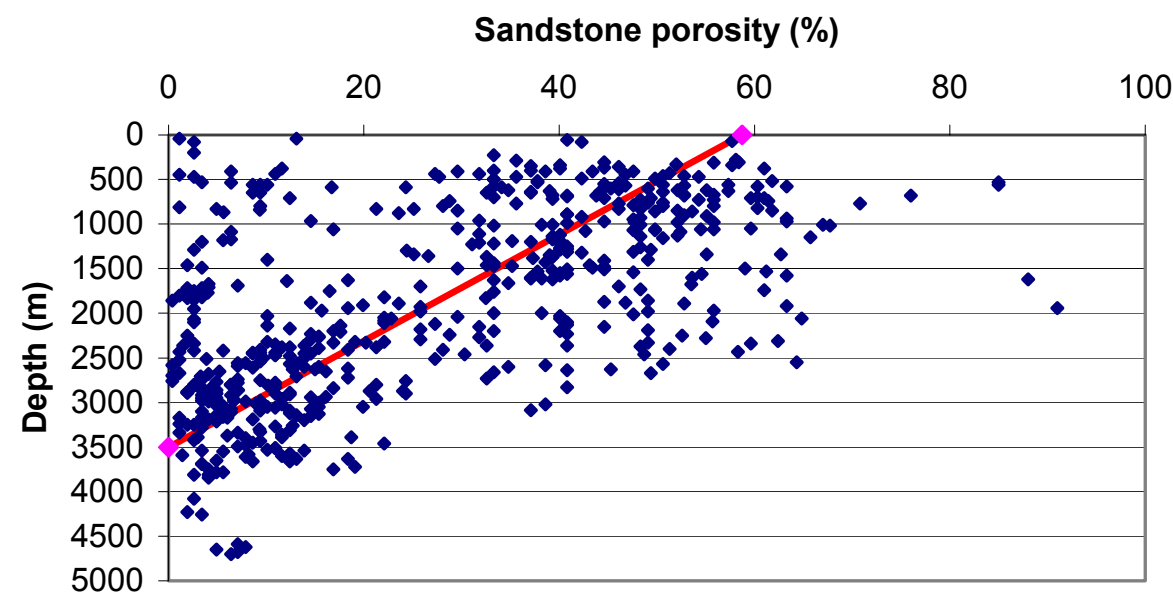

Fig. 4: Depth Vs Sandstone profile for wells in Chad Basin.

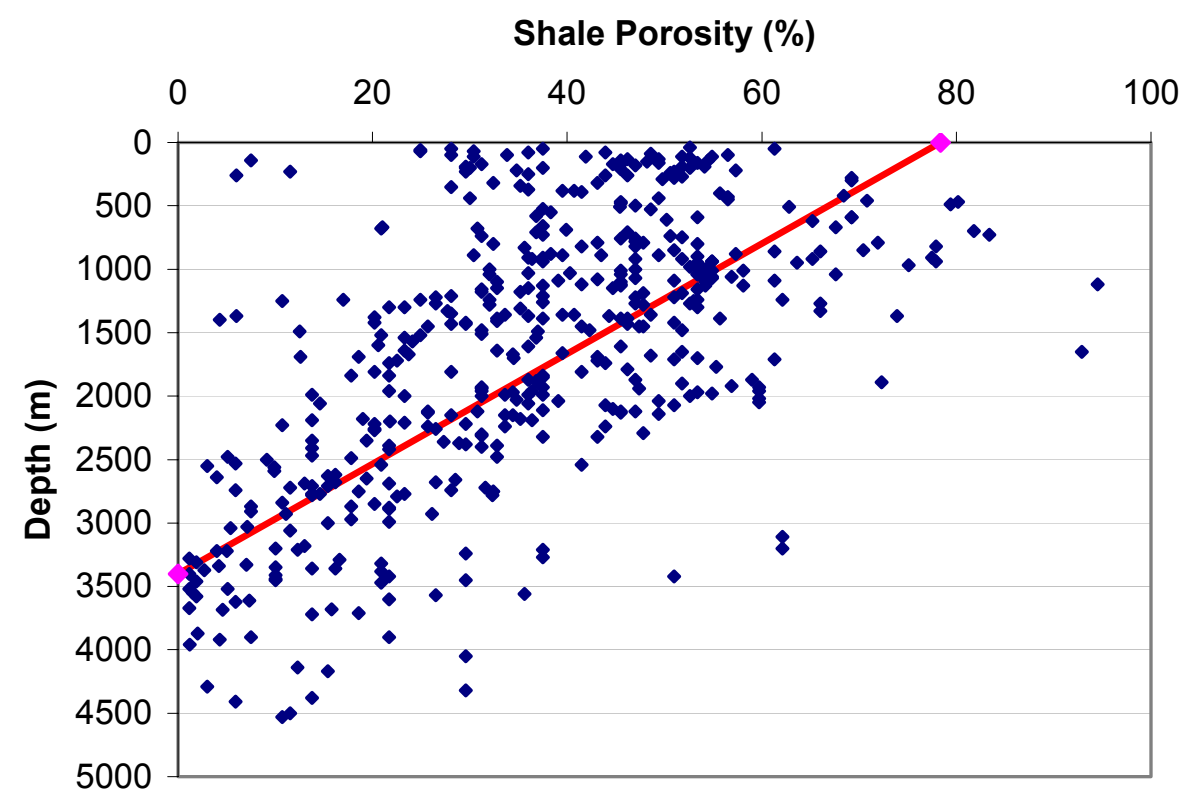

Fig 5: Depth Vs Shale Porosity profile for wells in Chad Basin 


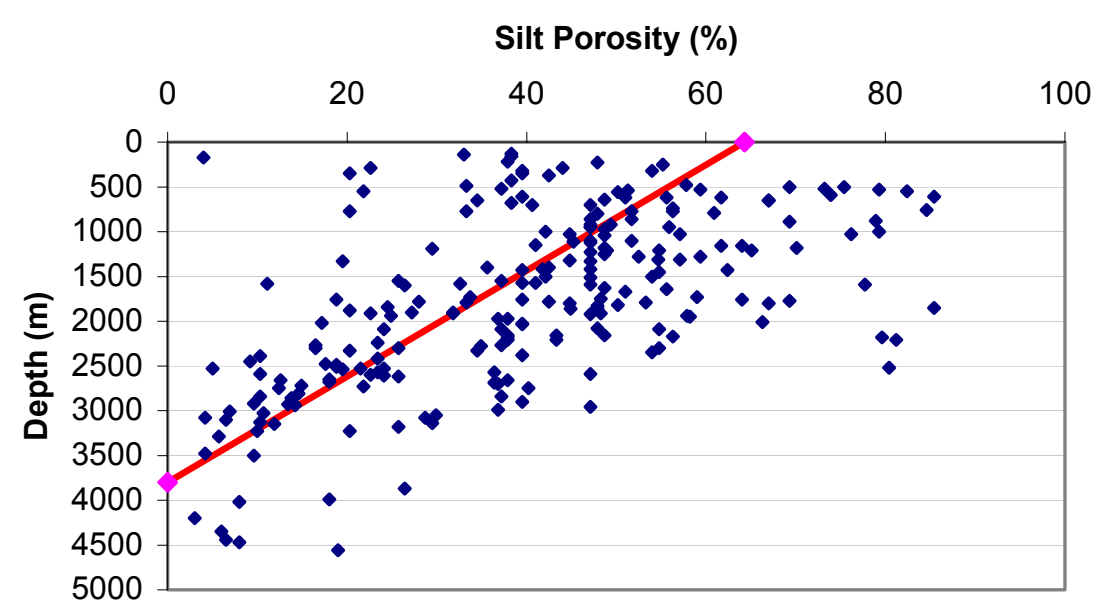

Fig 6: Depth Vs Siltstone Porosity profile for wells in Chad Basin

\section{Thermal conductivities and Heat flow}

The thermal conductivity $\mathrm{K}_{\mathrm{s}}$, of a rock sample can be expressed as a function of the conductivity of the solid matrix $\mathrm{k}_{\mathrm{m}}$, the conductivity of the pore fluid water $\mathrm{k}_{\mathrm{f}}$, and the porosity $\varphi$, as

$$
\mathrm{K}_{\mathrm{s}}=\mathrm{k}_{\mathrm{f}}^{\varphi} \mathrm{k}_{\mathrm{m}}^{1-\varphi}
$$

This relationship follows from the fact that thermal conductivity is lower in water than it is in minerals and hence, increases with decreasing porosity and increasing depth of burial. For solid phase that contains several elements the bulk thermal conductivity is calculated from geometrical model applied to matrix conductivity:

$$
\mathrm{k}_{\mathrm{m}}=\mathrm{k}_{1} \alpha_{1} \mathrm{k}_{2} \alpha_{2}-----------\mathrm{k}_{\mathrm{n}} \alpha_{\mathrm{n}}
$$

where $\mathrm{k}_{\mathrm{n}}$ represents the thermal conductivity of the principal constituents and $\alpha_{n}$ their volumetric proportion.

Equation (6) has been used to estimate the effective thermal conductivities for each well in the Chad Basin. A mean range of 1.70 and $3.11 \mathrm{Wm}^{-1}{ }^{\circ} \mathrm{C}^{-1}$ and an average value $2.35 \mathrm{Wm}^{-1}{ }^{\circ} \mathrm{C}^{-1}$ were computed for the various wells. Figure 7 shows the conductivity variation for Kanadi-1 Well. Values of conductivities computed for the various wells indicate that the Bima Sandstones are more conductive than the Chad and Kerri-Kerri Formations, which are characterized by clays and flat lying grits intercalations. The Fika Shale however, is found to be least conductive.

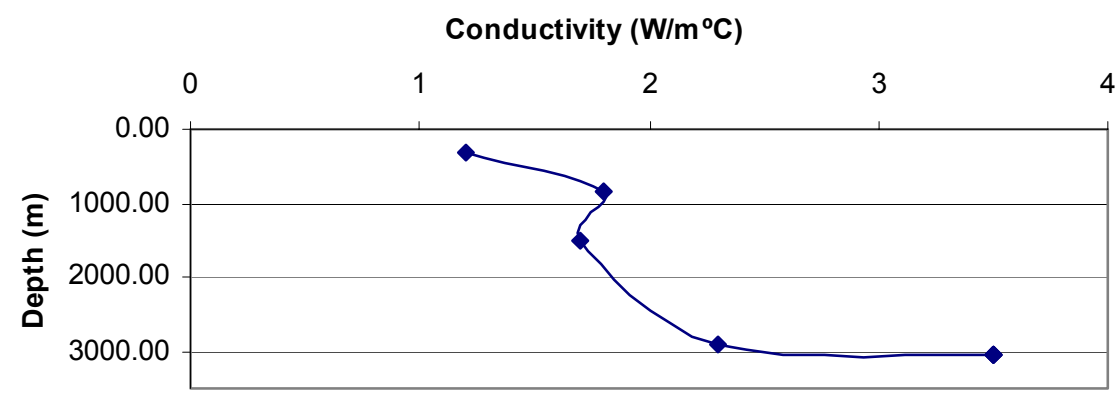

Fig. 7: Depth Vs Conductivity profile for Kanadi-1 Well 
The general relation governing heat conduction is Fourier's law, which in one dimension takes the form:

$$
\mathrm{q}=-\mathrm{kdT} / \mathrm{dZ}
$$

where $\mathrm{q}=$ heat flux

$\mathrm{k}=$ thermal conductivity, and $\mathrm{dT} / \mathrm{dZ}=$ geothermal gradient
The above steady state heat conduction equation (7) has been applied in estimating the heat flow values. The geothermal gradient was computed from the bottom hole temperature data from the study area (Nwankwo, 2007).

Mean heat flow values vary from 63.6 computed in Masu-1 well to $105.6 \mathrm{mWm}^{-2}$ obtained in Tuma-1 well. An average heat flow density of $80.6 \mathrm{mWm}^{-2}$ was computed for the Chad Basin. Figure 8 depicts the present day heat flow variation for Kanadi-1 well. The heat flow distribution for the oil wells in the basin is represented in Figure 9 while the surface heat flow map of the basin is shown in Figures 10.

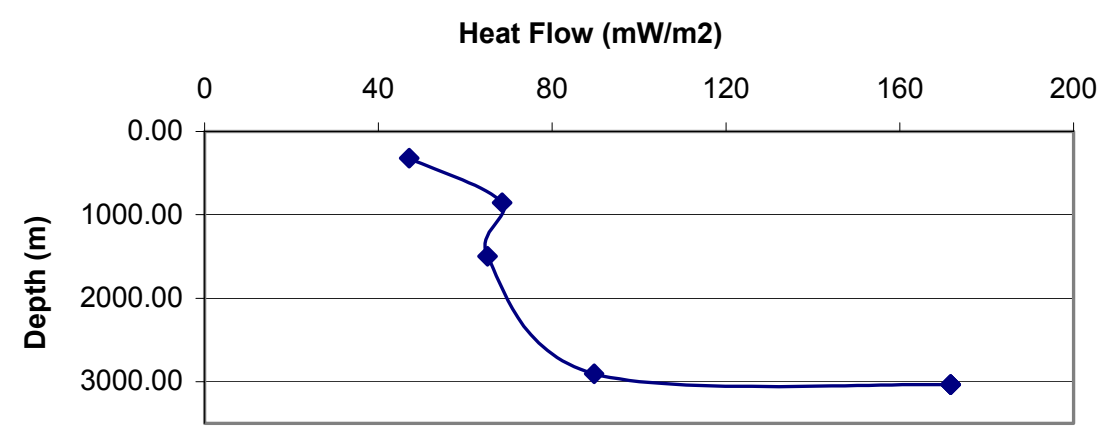

Fig. 8: Depth Vs Heat flow profile for Kanadi-1 Well

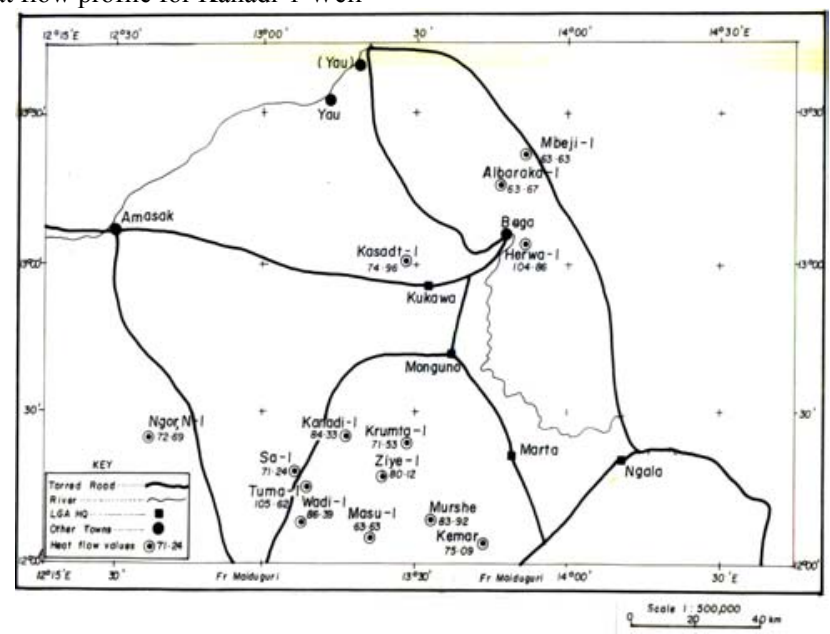

Fig. 9: Heat flow distribution for wells in the Chad Basin Nigeria.

Basin porosity varies with lithology and depth. Shallow and intermediate intervals have moderate to high porosities. These values however decrease sharply in Bima Formation, where values as low as 2 $\%$ were recorded. A porosity range of 2 to $79 \%$ and average of $35 \%$ were computed for Chad Basin. Most reservoir rocks have porosities greater than 10 percent and thickness greater than $3 \mathrm{~m}$. The porosity values computed in this study therefore indicate that the Chad Basin has a profitable reservoir rock. Also a mean thermal conductivity range of 1.70 and 3.11 $\mathrm{Wm}^{-1}{ }^{\circ} \mathrm{C}^{-1}$ and an average value $2.35 \mathrm{Wm}^{-1}{ }^{\circ} \mathrm{C}^{-1}$ computed for the various wells in the basin fall

* Corresponding author: Nwankwo, Cyril N. 
within the range of what is obtained in other petroliferous basins.

The average surface heat flow of $80.6 \mathrm{mWm}^{-2}$ as computed from this study is relatively higher than what has been estimated from the adjoining Anambra Basin $\left(48 \mathrm{mWm}^{-2}\right.$ to $\left.76 \mathrm{mWm}^{-2}\right)$, Niger Delta $(39.70$ $\mathrm{mWm}^{-2}$ to $64.28 \mathrm{mWm}^{-2}$ ), and some other similar sedimentary basins of the world. This regional variation in heat flow may be associated with the differences in thermal conductivity of rocks, geothermal gradients variations and ground water movement. Poor data quality as well as activities of intrusives that has been acclaimed to be prevalent in this basin is other factors that can result to high heat flow variations

High heat flows are characteristics of active volcanic arcs and actively extending terrains. Thus, intrusion of a sill into sedimentary rocks can locally change the temperatures and heat flow by orders of magnitude. The basin is hence more vulnerable to tectonic activities than the nearby Anambra and Niger Delta Basins

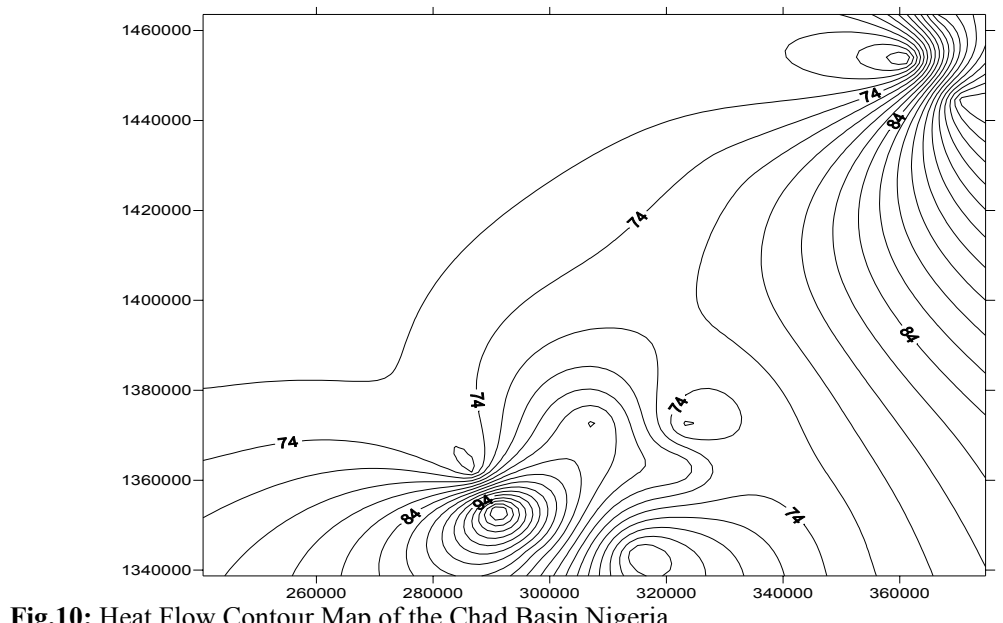

Fig.10: Heat Flow Contour Map of the Chad Basin Nigeria

Onuoha and Ekine (1999) obtained a mean heat flow value of $56.16 \mathrm{mWm}^{-2}$ and a range of 48 to $76 \pm 3$ $\mathrm{mWm}^{-2}$ for Anambra Basin. Uko (1996) utilizing the thermal resistance method in his work in Northern Niger Delta estimated a simple average heat flow of $51.49 \mathrm{mWm}^{-2}$, with a standard deviation of 3.2 $\mathrm{mWm}^{-2}$. Henrikson and Chapman (2002) determined a mean heat flow of $91 \mathrm{mWm}^{-2}$ for Utah.

In an ideal steady state conductive situation, heat flow does not vary with depth. Any variation in heat flow indicates changes in thermal conductivity due to facies changes in rock type and/or ground water movement. There was no defined trend in the variation of heat flow values obtained in this study. However, the heat flow values are relatively higher at the center and lower in the wells located at the northeast and southwest region.

\section{Implications for Hydrocarbon Potential}

Any prospective petroleum sediment must have a good quality source rock, good reservoir and seal lithologies, favourable regional pathways and trapping mechanisms. The Fika and Gongila Shale are the main source rocks in Chad Basin, while the reservoirs may be provided by sandstone facies in the same formations and in the Bima Sandstone. Also, the intrusive sills can provide good seal for hydrocarbons. The aquifers within the Chad Formation can act as a conduit for hydrocarbon to the surface.

The computed heat flow values for all the oil Wells in the basin suggests that its sediments should be thermally mature enough to generate hydrocarbons; hence with necessary exploration precautions being put in place future discovery of oil and/or gas in commercial quantity is possible in the Nigerian Chad Basin.

\section{CONCLUSION}

Heat flow values computed in this study vary from well to well; and a regional range of 63.6 to 105.6 $\mathrm{mWm}^{-2}$ obtained for the basin fall within the range of what is common in other petroliferous basins of the world. But the fact that oil or gas is yet to be found in commercial quantity in the Nigerian sector of the Chad Basin do not rule out the possibility of having oil/gas reservoirs in this basin. There is no doubt that the Nigerian inland basins as a whole have been highly under explored probably because of the poor knowledge of their geology, and the abundance of oil in the Niger Delta. Continuous basinal analysis, finetuning of the seismic data acquisition and interpretation techniques will help to enhance seismic data resolution, data quality and detect intrusive.

* Corresponding author: Nwankwo, Cyril N. 
Consequently, there will be an improvement in prospects of commercial discovery of hydrocarbon in the area.

\section{REFERENCES}

Azarma, AA; Goni, IB; Goni, A, (2004). Petroleum Potentials and Prospects of the Nigerian sector of the Chad basin; a review .

Henrikson, A; Chapman, DS (2002). Terrestrial heat flow in Utah. Dept of Geology and Geophysics, University of Utah, Salt Lake City Utah.

Nwankwo, CN (2007). Heat flow studies and hydrocarbon maturation modeling in the Chad Basin, Nigeria. Unpublished Ph.D dissertation, University of Port Harcourt.
Obaje, NG; Wehner, H; Scheeder, G; Abubakar, MB; Jauro, A (2004). Hydrocarbon prospectivity of Nigeria's inland basins: From the viewpoint of organic geochemistry and organic petrology. AAPG Buletin, 88, 3, 325-353.

Okosun, EA (1995). Review of the geology of Bornu basin. Journ. Mining and Geol vol. 31 (2), 113172.

Onuoha, KM; Ekine, AS (1999). Subsurface temperature variationsand heat flow in the Anambra basin, Nigeria. J. of African Earth Sciences, 28, 3. 641-652.

Uko, ED (1996). Thermal modeling of the Northern Niger delta. Unpublished Ph.D Thesis, University of Science and Technology, Port Harcourt.

* Corresponding author: Nwankwo, Cyril N. 